\title{
A literature review and case report of hand, foot and mouth disease in an immunocompetent adult
}

\author{
Carlos Omaña-Cepeda 1,2, Andrea Martínez-Valverde², María del Mar Sabater-Recolons ${ }^{2,3}$, Enric Jané-Salas ${ }^{2,3}$, \\ Antonio Marí-Roig ${ }^{2,4}$ and José López-López ${ }^{2,3,5^{*}}$
}

\begin{abstract}
Background: To report an uncommon case of hand, foot and mouth disease, (HFMD) in an immunocompetent adult; a highly infectious disease, characterized by the appearance of vesicles on the mouth, hands and feet, associated with coxsackieviruses and enteroviruses; including a literature review.

Case report: A 23 year Caucasian male with no medical or surgical history, no allergies, was not taking any medication and smoked ten cigarettes a day, suffering from discomfort in the oral cavity; itching, burning and pain when swallowing associated with small erythematous lesions located on the hard palate, and small ulcers in tonsillar pillars and right buccal mucosa. Mild fever of $37.8^{\circ} \mathrm{C}$ and general malaise. The patient reported he had had contact with a child diagnosed with HFMD. From his background and symptoms, the patient was diagnosed with HFMD. Following symptomatic treatment, the symptoms remitted in 7 days.
\end{abstract}

Methods: A literature review in MEDLINE (PubMed). The inclusion criteria were for studies on humans over the last 5 years, using the keywords HFMD.

Results: We found 925 articles, which were subsequently reduced to 52 documents after applying the inclusion criteria. Maculopapular lesions were found on hands and feet.

Conclusions: Dentists may have a key role diagnosing the disease. A surveillance system to predict future outbreaks, encourage early diagnosis, put appropriate public health measures in place and research vaccine development is vitally important in order to control the disease.

Keywords: HFMD, Immunocompetent, Adult, Dentistry, Oral health, Case report

\section{Background}

In 1958, Robinson et al. first described the outbreak of a highly infectious disease in Toronto in 1957, characterized by the appearance of vesicles on the mouth, hands and feet [1]. It was isolated coxsackievirus (CV) A16. Hand foot and mouth disease (HFMD) rarely appears as an epidemic infectious disease. However it is the most common infectious disease in China, with an incidence rate of around 500,000-1,000,000 cases

\footnotetext{
*Correspondence: 18575jll@gmail.com

${ }^{5}$ Dental Hospital Barcelona University, Universitary Campus of Bellvitge,

C/Feixa LLarga S/N, L'Hospitalet de Llobregat, 08907 Barcelona, Spain

Full list of author information is available at the end of the article
}

per year [2]. It is associated with climate changes, usually occurring in spring and summer [3]. It occurs most often in children between 0 and 5 years old $[4,5]$ and immunocompromised adults [6], due to their high sensitivity to the enterovirus 71 (EV71) and CVA16 [7]. However, it can also occur in immunocompetent adults $[5,6]$. Some of the major causative agents are EV71, CVA16 [8], and it was recently described, CVA6 and CVA10 [9-11].

The main routes of transmission are person-to-person (through oral-pharyngeal secretions or by direct vesicle contact), via contaminated water (fecal-oral route) [12], and via contaminated objects. 
The incubation period is short, ranging from 2 to 7 days. It shows non-specific symptoms, but there may be mild fever and catarrhal manifestations. The initial viral implantation is in the oral cavity and ileum, spreading to the regional lymph nodes within $24 \mathrm{~h}$. Viremia occurs after $72 \mathrm{~h}$, followed by secondary infection and viral seeding in areas such as the oral mucosa, hands and feet. On the seventh day, there is an increase in antibody levels and the disease begins to disappear [13].

Oral lesions are the first clinical signs of the disease, and are sometimes the only sign, because they appear even before the lesions on the extremities [12]. Manifestations of the disease on the skin consist of multiple lesions on the hands and feet, and occur concurrently or shortly after the oral lesions. Systemic features are summarized in the Table $1[13,14]$.

A study in Japan suggests the possibility that the HFMD could also cause opsoclonus-myoclonus (jerky eye movements in all directions) as a possible viral or autoimmune response [15], other studies reports cases of retinopathy and vision loss in this entity [16].

The diagnosis is by observing the clinical signs of the disease, such as fever and the characteristic lesions on the hands, feet and mouth. Confirmation of diagnosis is carried out by isolating the virus responsible for the disease, or by identifying virus-neutralizing antibodies in patient serum [5].

There are varieties of studies investigating possible treatments for HFMD. One such study considers using intravenous immunoglobulin (IVIG) as therapy against HFMD [17, 18]. However, because the disease is selflimiting in nature and due to the lack of a virus-specific therapy, the present treatment is symptomatic. Non-specific rinses with anesthetic substances can be employed to relieve oral discomfort. In addition, ensure that the patient gets plenty of fluids and avoids spicy and acidic foods, and foods that require a lot of chewing.

In most cases, the prognosis is good moving toward spontaneous healing within 7-10 days without sequelae, scabs or scars. However, there have been reports of onychomadesis associated with the disease [19-21], in addition to neurological disorders such as meningitis (EV-4) [22], Guillain-Barre syndrome, meningoencephalitis, as well as paralytic polio, myoclonus and somnolence, mainly caused by the sub genotype C4aEV71 [23], in children under 5 years (the main risk group in the population) [24]. It has been shown that most of these patients have low levels of vitamin A, associated with reduced immunity, and they are therefore more susceptible to a more severe manifestation of the disease [25]. Note also that delays in access to health services lead to an increased likelihood of a more severe form of the disease $[4,26,27]$.

The aim of this article is to present a case of HFMD in an immunocompetent adult, alongside a literature review. The article also aims to identify the etiologic agents and publicize transmissible factors in order to correctly diagnose patients, and thus to establish an effective treatment plan both individually and collectively.

\section{Case report}

In May 2014, coinciding with the springtime, a 23 year Caucasian male went to the Odontology Hospital of the University of Barcelona. He had no familiar, medical or surgical history, no allergies, not taking any medication and smoked ten cigarettes a day. He was suffering from discomfort in the oral cavity: itching, burning and pain when swallowing associated with small erythematous lesions located on the hard palate, and small ulcers in tonsillar pillars and right buccal mucosa. The patient had a mild fever of $37.8{ }^{\circ} \mathrm{C}$ and general malaise. The examination also found maculopapular lesions on the hands and feet, some of which were in the form of blisters (Figs. 1, 2 and 3). Upon questioning the patient, he stated that a few days earlier (7-10 days), he had been in contact with a 2-year-old girl who was diagnosed with HFMD, and that other members of the child's family had suffered the same symptoms.

From his background and symptoms, the patient was diagnosed with HFMD and symptomatic treatment was begun with analgesics (650 mg paracetamol three times a day), hygiene, and a diet that would not irritate the symptoms further. The patient controlled the symptoms for 7 days until the disease subsided. An analytical control was requested in which no evidence of any significant alteration was shown. We conducted a follow-up visit after 15 days and did not find any residual lesions.

Table 1 Systemic manifestations oh HFMD [14, 15]

\begin{tabular}{lc}
\hline Systemic features of HFMD & Systemic features in severe occurrences of HFMD \\
\hline $\begin{array}{l}\text { Anorexia, fever, low pollution, sore throat, runny nose, abdominal } \\
\text { pain, and sometimes myalgia, lymphadenopathy, diarrhea, nausea } \\
\text { and vomiting }\end{array}$ & $\begin{array}{c}\text { Skin rashes, fever } \geq 38^{\circ} \mathrm{C} \text {, neurological symptoms, respiratory symptoms } \\
\text { such as tachypnea or bradypnea, pulmonary edema, cardiovascular } \\
\text { symptoms such as tachycardia and hypertension, bleeding, pulmonary } \\
\text { consolidation, hyperglycemia, elevated leukocyte and high levels of lactic } \\
\text { acid }\end{array}$ \\
\hline
\end{tabular}




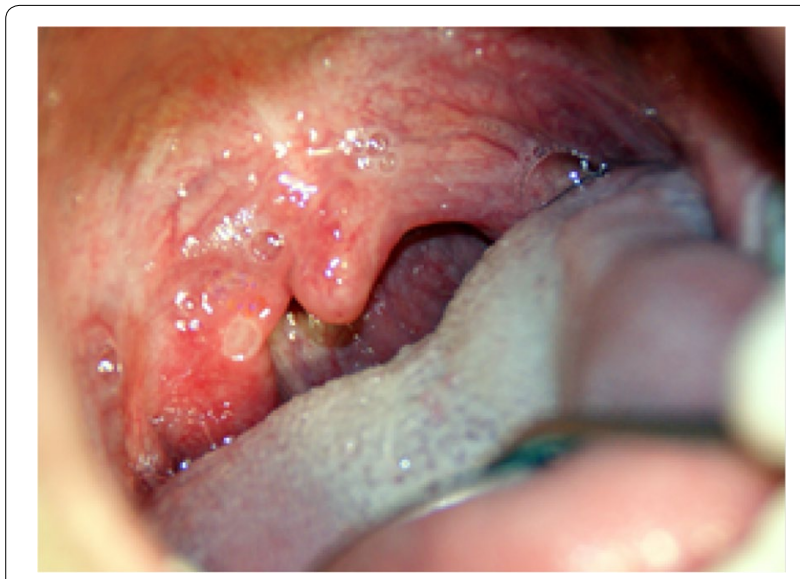

Fig. 1 Lesions on the hard palate, soft and tonsillar pillars
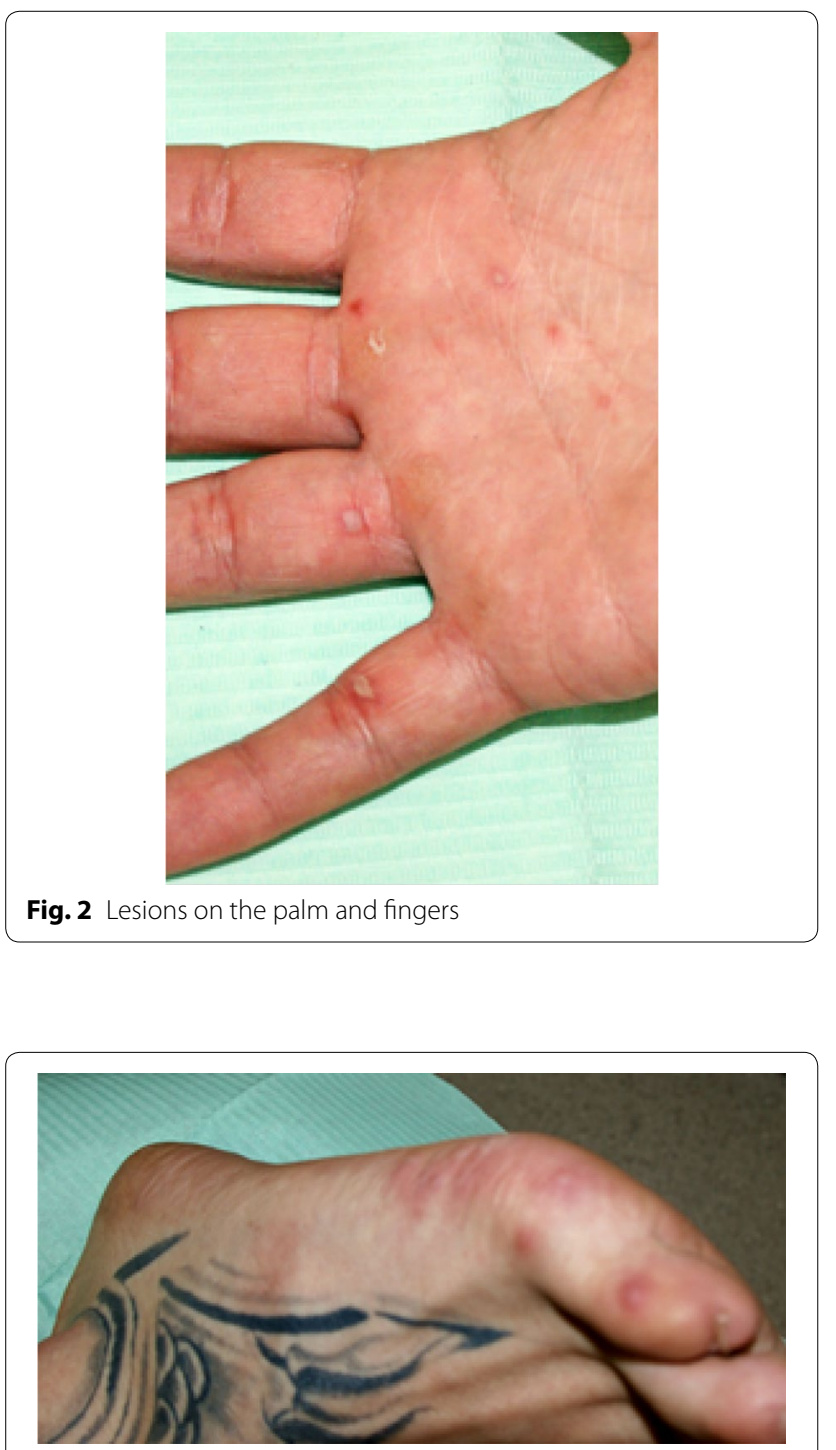

Fig. 3 Lesions on the foot

\section{Methods and results}

A literature review was performed via an automated search for information on the database: MEDLINE (PubMed) to identify and summarize all relevant publications on HFMD. The search strategy was based on the terms HFMD. The inclusion criteria was for studies on humans, over the last 5 years that identify the etiologic agents, disclose communicable factors, correctly diagnose the patients, and establish an effective treatment plan both individually and collectively. We assessed the eligibility of articles from the titles and abstracts, and extracted the information related to our target subject. We also included an article by Delgado et al. [13], as well as two older articles for their importance to the history of the disease: Robinson et al. [1], and Alsop et al. [28].

We found 925 publications in PubMed with the keywords listed, of which 627 were based on humans and published in the last 5 years, which was reduced to 92 , when we limit the search to studies in adults. We selected 49 papers that met the objectives of our research and the inclusion criteria. We included 26 of the 52 total papers as a systematic review, based in the number of cases presented and type of studies, and addressing the issues developed: the relationship between climate changes and HFMD, causes, complications and epidemiological studies on severe forms of HFMD, the remaining papers was included for the discussion and development of theme (Fig. 4).

\section{Discussion}

HFMD is a syndrome caused by intestinal viruses from the Picornaviridae family, and is mainly characterized by the appearance of vesicular lesions on the mouth, hands and feet. It is more common in children under 10 and in vulnerable adults. Nonetheless, it can also occur in young immunocompetent adults $[6,9-11,15]$, as in the case reported.

For this review, we will build on the most relevant items and features that in relation with the HFMD are described in the selected papers.

\section{Climate}

Recent studies suggest a strong association between HFMD and climate changes, as the incidence of the disease increases in the springtime, when our case occurred. However, the exact reason for this association has not been studied yet. Different studies show contradictions in temperatures, while Wang et al. [4] provides the greatest incidence range between 21.1 and $26.6{ }^{\circ} \mathrm{C}$. A study by Hii et al. [29] cites data above $32{ }^{\circ} \mathrm{C}$ and in periods where the temperature difference between the minimum and the maximum is greater than $7{ }^{\circ} \mathrm{C}$. Neither is rainfall a clear risk factor, since according to Wang et al. [4] there are 


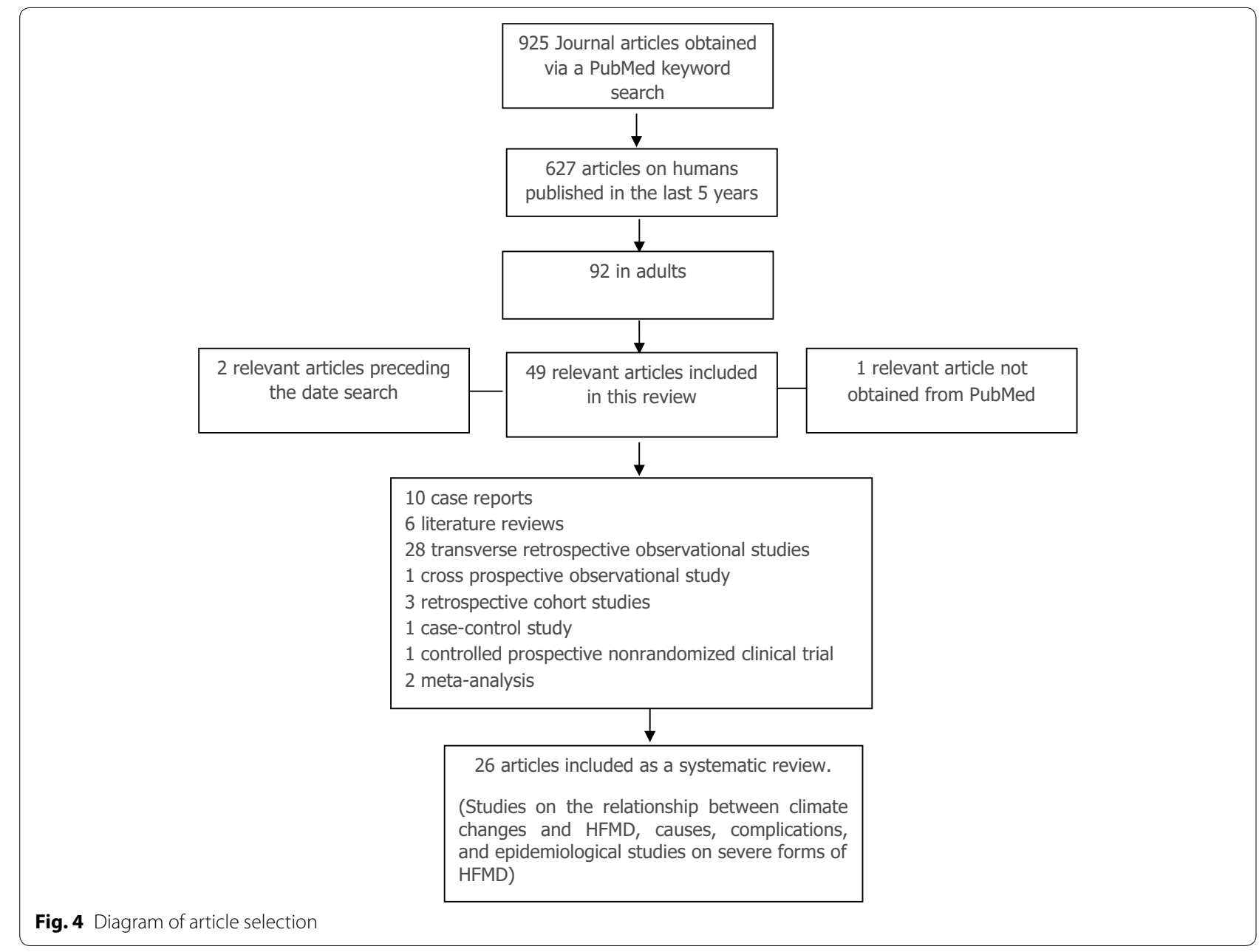

more cases with high rainfall, while for others [29] there is a low incidence rate $0.5 \%$ for rainfall above $75 \mathrm{~mm}$ (Table 2). The biological relationship between climate indicators and EV activity is quite complicated and different reports on the subject do not reveal the same results, so it deserves to be investigated in future studies to get better information on this relationship [2, 29].

\section{Sex}

As for sex, recent studies suggest a higher prevalence in males than in females $[4,26,30]$. In contrast, no significant differences have been demonstrated in the genre and viral load between mild and severe cases [23].

\section{Etiology}

The main causative agents are CVA16 and EV71 [17]. Moreover, outbreaks caused by CVA4, CVA5, CVA6, CVA9, CVA10, CVA12, CVB1, CVB3 and CVB5 have been observed [3, 9-11, 31-34]. Links have also been found between EV-4, HFMD and meningitis [22]. There is a low incidence in the cases documented in Europe, with a greater predominance of CVA16 infections. In contrast, in Asian countries such as China, the actual incidence of this disease is much higher and it has been shown that there is a large predominance of the EV71 virus in these countries, in particularly genotype C4 where the cases appear to be more severe (Table 3).

\section{Diagnosis and differential diagnosis}

Diagnosing the disease is relatively easy by looking at the clinical features of the disease.

In oral mucosa, an enanthem appears after 1-2 days and on the soft palate, inner cheeks, gums, gingivallabial groove and tongue. In our case study, the lesions appeared in less common areas such as the hard palate, tonsillar pillars and the right buccal mucosa. It consists of 5-10 small vesicles, which are very painful, covered with a yellowish pseudomembrane and surrounded by an erythematous halo. They measure between 3 and $7 \mathrm{~mm}$ in diameter (typically $5 \mathrm{~mm}$ ). The enanthem breaks, forming small ulcers, as the oral epithelium is thin, which allows the vesicles to break easily during movements 
Table 2 Studies on the relationship between climate changes and HFMD

\begin{tabular}{|c|c|c|}
\hline Study & Results & Conclusions \\
\hline $\begin{array}{l}\text { HanWang et al. Bei- } \\
\text { jing, China } 2011 \text { [4] }\end{array}$ & $\begin{array}{l}\text { Spring OR }=1.4-1.6 \\
\text { Other seasons } O R \leq 1.2 \\
\text { Increased risk of transmission: } \\
\text { Temperature } 21.1-26.6^{\circ} \mathrm{C} \\
\text { High relative humidity } \\
\text { Low wind speed } \\
\text { High rainfall } \\
\text { High population density } \\
\text { Schools open }\end{array}$ & $\begin{array}{l}\text { Strong relationship between climatic factors } \\
\text { and the transmission of HFMD }\end{array}$ \\
\hline $\begin{array}{l}\text { Hii et al. Umeå, Swe- } \\
\text { den } 2011 \text { [29] }\end{array}$ & $\begin{array}{l}\text { With each degree Celsius that the maximum temperature rises } \\
\text { above } 32^{\circ} \mathrm{C} \text {, the risk of disease incidence increases by } 36 \% \\
\text { Rainfall below } 75 \mathrm{~mm} \text { increases risk by } 0.3 \% \text {. Above } 75 \mathrm{~mm} \text {, risk fell } \\
\text { by } 0.5 \% \\
\text { Temperature differences of more than } 7{ }^{\circ} \mathrm{C} \text { between the minimum } \\
\text { and maximum temperature increase the incidence rate by } 41 \%\end{array}$ & $\begin{array}{c}\text { The results suggest a strong association } \\
\text { between HFMD and climate changes }\end{array}$ \\
\hline $\begin{array}{l}\text { Park et al. South } \\
\text { Korea, } 2010 \text { [12] }\end{array}$ & $\begin{array}{l}\text { Having a non-water closet toilet, changes in water quality, and } \\
\text { contact with HFMD patients were associated with risk of HFMD } \\
(\mathrm{OR}=3.3,2.8,6.9 \text {, and } 5.0 \text {, respectively) } \\
\text { Visiting a hospital, changes in water quality, presence of a skin } \\
\text { wound, eating out, and going shopping were significantly associ- } \\
\text { ated with the risk of HFMD (OR }=9.0,37.0,11.0,12.0,37.0 \text {, and } \\
\text { 5.0, respectively) }\end{array}$ & $\begin{array}{l}\text { The results suggest that seasonal variations, } \\
\text { geographic localization, person to-person } \\
\text { contact and contaminated water could be } \\
\text { the principal modes of transmission of HFMD }\end{array}$ \\
\hline
\end{tabular}

HFMD hand, foot and mouth disease

associated with speech and chewing. These vesicles can hinder food consumption because the tongue may be swollen and painful [13] (Fig. 1).

Skin vesicles can vary in number from a few to 100 . Characteristically, they appear on the sides and back of the fingers, around the nails, around the heel and on the palm of the hand and soles of the feet. Occasionally they can appear on the knees and buttocks. Skin lesions, in our case, appeared on the sides and backs of the fingers and toes of our patient, and appeared in the locations described elsewhere. It measures approximately $3-7 \mathrm{~mm}$ in diameter. They are surrounded by an erythematous halo. The vesicle wall is thin and may be preceded by a maculopapular rash. They move into vesicular stage and then go on to develop scabs and ulcers [6, 13] (Figs. 2, 3).

Histopathological examination of skin vesicles revealed the presence of intraepithelial vesicles, within which there are fibrin, epithelial cells and reticular degeneration balonica, neutrophils, mononuclear cells and eosinophilic proteinaceous content [13].

In the differential diagnosis of lesions on the oral mucosa, the lesions that should be considered are primary herpetic gingivostomatitis, herpangina, erythema multiforme, aphthous stomatitis and chickenpox. It is very important to establish a correct diagnosis to avoid prescribing inappropriate drugs $[17,35]$.

Although it is not a serious disease, an early diagnosis is important to avoid epidemics on the pediatric population. There must be communication between the different branches of medicine and dentistry. The role of the dentist is important, as he/she is one of the professionals who must help with diagnosis when the patient seeks professional advice for painful oral lesions. Another diagnostic method studied recently by $\mathrm{Yu}$ et al. is the use of IgM ELISA in EV71 and CVA16 infections to correctly identify the virus causing the disease in patients [36].

\section{Complications}

Cases of HFMD associated with onychomadesis have been documented. This relates to the fact that viral replication could damage the nail matrix and produce transient nail dystrophy. Although several cases have been documented for patients infected with CVA10, further studies are needed to determine the causative agent of HFMD associated with onychomadesis [13]. It is not necessary to treat the nails in any way except by keeping the area clean and avoiding further injury. In all of the reported cases, the nail disorders resolved themselves spontaneously over the course of several weeks [21] (Table 4).

Complications have been cited on a neurological level, and early recognition of the children at risk is the key to reducing mortality and severe morbidity [7, 37, 38] (Table 3). It was therefore shown that administration of mannitol, methylprednisolone, IVIG and other supportive treatments may prevent the disease worsening in 
Table 3 Studies related to the causes of HFMD

\begin{tabular}{|c|c|c|}
\hline Study & Results & Conclusions \\
\hline $\begin{array}{l}\text { Zhu et al. Beijing, China } \\
2009 \text { [27] }\end{array}$ & $\begin{array}{l}51 \text { cases with HFMD } \\
25 \text { CVA16 positive cases } \\
4 \text { C4aEV71 positive cases } \\
7 \text { Cases neither positive for EV71 nor CVA16 }\end{array}$ & $\begin{array}{l}\text { In } 2007 \text { in China there was a higher incidence of HFMD } \\
\text { caused by CVA16 }\end{array}$ \\
\hline $\begin{array}{l}\text { Osterback et al. Turku, } \\
\text { Finland } 2009 \text { [31] }\end{array}$ & $\begin{array}{l}35 \text { cases with HFMD } \\
34 \text { CVA6 positive cases }\end{array}$ & CVA6 is emerging as the primary cause of the disease \\
\hline $\begin{array}{l}\text { Zhang et al. Pekín, } \\
\text { Beijing } 2009 \text { [5] }\end{array}$ & $\begin{array}{l}70 \text { cases with HFMD } \\
30 \text { Positive for enterovirus initiation: } 66.7 \% \text { positive } \\
\text { for EV71 } \\
\text { At } 4 \text { days: } 66.7 \% \text { positive for EV71 } \\
\text { At } 5 \text { days: } 12.9 \% \text { positive for EV71 }\end{array}$ & $\begin{array}{l}\text { Samples must be collected within } 4 \text { days after the onset of } \\
\text { the disease, because there is more likelihood of positive } \\
\text { viral detection }\end{array}$ \\
\hline $\begin{array}{l}\text { Blomgvist et al. Helsinki, } \\
\text { Finland } 2010 \text { [3] }\end{array}$ & $\begin{array}{l}317 \text { cases with HFMD } \\
212 \text { positive cases of CVA6 and/or CVA10 }\end{array}$ & $\begin{array}{l}\text { Outbreak due to new genetic variants of the Coxsackie } \\
\text { virus, CVA10 and CVA6 }\end{array}$ \\
\hline $\begin{array}{l}\text { Rabenau et al. Frankfurt, } \\
\text { Germany } 2010 \text { [52] }\end{array}$ & $\begin{array}{l}696 \text { cases with HFMD } \\
88-73 \% \text { of children under } 4 \text { years are susceptible to } \\
\text { infection } \\
30.6 \% \text { seropositive for both viruses } \\
43.5 \% \text { neutralizing antibodies (Ntab) } \\
25.9 \% \text { did not have antibodies }\end{array}$ & $\begin{array}{l}\text { The seroprevalence study shows a common dissemination } \\
\text { of CVA16 and EV71 in Germany, and a comparatively } \\
\text { higher sensitivity in the younger population }\end{array}$ \\
\hline $\begin{array}{l}\text { Liu et al. Nanchang, } \\
\text { China } 2011[14]\end{array}$ & $\begin{array}{l}109 \text { cases with HFMD } \\
90 \% \text { children under } 8 \text { years } \\
\text { High prevalence of subgenotype C } 4\end{array}$ & $\begin{array}{l}\text { C4aEV71 genotype is now the more common infectious } \\
\text { agent in China }\end{array}$ \\
\hline $\begin{array}{l}\text { Yang et al. Beijing, China } \\
2011[32]\end{array}$ & $\begin{array}{l}301 \text { cases with HFMD } \\
\text { Enterovirus (HEV) (88.4\%), EV71 (50.4\%), CVA16 } \\
\text { (38.3\%), CVA4 (1.1\%), CVA6 (1.1\%), CVA10 (1.1\%), } \\
\text { CVA12 (2.6\%), CVB (5.3\%) }\end{array}$ & $\begin{array}{l}\text { HFMD epidemics can persist for a long time in China, due } \\
\text { to the different genetic variations in the composition } \\
\text { of the virus, enteroviral characteristics of recombination } \\
\text { and co-infection, increased travel, migration and the lack } \\
\text { of an effective vaccine }\end{array}$ \\
\hline $\begin{array}{l}\text { Yan et al. Shanghai, } \\
\text { China } 2011[30]\end{array}$ & $\begin{array}{l}3208 \text { HFMD cases } \\
\text { EV71-86.5\%, CVA16-6.9\%, CVA16 + EV71-17.6\% } \\
\text { Children 1-4 years } 76.9 \% \\
\text { M:F-65.3\%: } 34.7 \% \\
\text { Subgenotype C } 4 \text { of EV71 circulating }\end{array}$ & $\begin{array}{l}\text { The subgenotype C } 4 \text { of EV71 was the main causative } \\
\text { agent of the epidemic in Shanghai. The group most } \\
\text { affected were children under } 4 \text { years. There was a higher } \\
\text { prevalence in boys than in girls. High incidence of mixed } \\
\text { infections of EV71 and CVA16 }\end{array}$ \\
\hline $\begin{array}{l}\text { Rabenau et al. Frankfurt, } \\
\text { Germany } 2010 \text { [52] }\end{array}$ & $\begin{array}{l}696 \text { cases with HFMD } \\
88-73 \% \text { of children under } 4 \text { years are susceptible to } \\
\text { infection } \\
30.6 \% \text { seropositive for both viruses } \\
43.5 \% \text { neutralizing antibodies (Ntab) } \\
25.9 \% \text { did not have antibodies }\end{array}$ & $\begin{array}{l}\text { The seroprevalence study shows a common dissemination } \\
\text { of CVA16 and EV71 in Germany, and a comparatively } \\
\text { higher sensitivity in the younger population }\end{array}$ \\
\hline
\end{tabular}

HFMD hand, foot and mouth disease

severe cases, and improve the rate of successful recovery in patients with nervous system complications [39] (Table 3).

\section{Severe forms}

It is worth noting the large number of reports on Asian patients with HFMD and severe neurological complications caused by EV71, which can rapidly progress to fulminant cardiorespiratory failure and death. All the above studies are consistent with the fact that EV71 is the virus most responsible for serious manifestations of HFMD, and children under 2-4 years are the main group at risk of such complications. However it has not yet been determined whether neutralizing antibody responses in the early stages of infection correlate with the clinical severity of the disease in patients with EV71 [40, 41] (Table 5).
In a meta-analysis by $\mathrm{Li}$ et al. [42], in mainland China and Taiwan, concluded that blood counts increased glucose and leukocytes in severe forms of the disease, are a tool that can help physicians to anticipate the diagnosis and treatment of these patients efficiently.

Fang et al. in 2014 [43], in a meta-analysis of Risk factors of severe HFMD, concluded that Duration of fever $\geq 3$ days, body temperature $\geq 37.5^{\circ} \mathrm{C}$, lethargy, hyperglycemia, vomiting, increased neutrophil count, EV71 infection, and young age are risk factors for severe HFMD. A confirmed diagnosis at first visit to hospital can significantly decrease the risk of severe HFMD.

Recently, cellular receptors have been identified, along with host factors that stimulate EV71. Several lines of research suggest that the scavenger receptor class B, member 2 (SCARB2) plays a crucial role in EV71 
Table 4 Studies related to the complications of HFMD

\begin{tabular}{|c|c|c|}
\hline Study & Results & Conclusions \\
\hline $\begin{array}{l}\text { Ooi et al. Sarawak, Malasia } \\
2009 \text { [7] }\end{array}$ & $\begin{array}{l}725 \text { HFMD cases } \\
\text { Risk factors: fever } \geq 3 \text { days (1), fever } \geq 38.5^{\circ} \mathrm{C}(2) \text {, lethargy history } \\
\text { (3) } \\
\geq 2 \text { factors present in } 65 \% \text { of children with pleocytosis in CSF, } \\
\text { compared to } 30 \% \text { without it } \\
\text { 2-3: S } 28 \% \text {, E } 89 \% \text {, PPV } 79 \% \text {, NPV } 50 \% \\
\text { 1: S } 75 \% \text {, E } 59 \% \text {, PPV } 75 \% \text {, NPV } 59 \%\end{array}$ & $\begin{array}{l}\text { There are three risk factors to identify children } \\
\text { with possible neurological disorders that } \\
\text { are easily identifiable: } \\
\text { Fever } \geq 3 \text { days duration } \\
\text { Fever } \geq 38.5^{\circ} \mathrm{C} \\
\text { History of lethargy }\end{array}$ \\
\hline $\begin{array}{l}\text { Cho et al. Seoul, Korea } \\
2010 \text { [23] }\end{array}$ & $\begin{array}{l}16 \text { HFMD cases associated with: meningitis (10), Guillain-Barré } \\
\text { syndrome ( } 3 \text { ), meningoencephalitis ( } 2 \text { ), poliomyelitis associated } \\
\text { with acute flaccid paralysis ( } 1 \text { ) myoclonus ( } 1 \text { ) } \\
11 \text { positive cases for C4aEV71 }\end{array}$ & $\begin{array}{l}\text { Most neurological manifestations are caused } \\
\text { by } C 4 \mathrm{eEV} 71\end{array}$ \\
\hline $\begin{array}{l}\text { Guimbao et al. Zaragoza, } \\
\text { Spain } 2010 \text { [20] }\end{array}$ & $\begin{array}{l}27 \text { Onychomadesis cases } \\
24 \text { had previously submitted HFMD } \\
\text { Virus CVB1 and } 2\end{array}$ & $\begin{array}{l}\text { Strong association between HFMD and } \\
\text { onychomadesis. Microbiological results } \\
\text { inconclusive }\end{array}$ \\
\hline $\begin{array}{l}\text { Davia et al. Valencia, Spain } \\
2011 \text { [19] }\end{array}$ & $\begin{array}{l}221 \text { Onychomadesis cases associated with HFMD: } 61 \% \\
\text { CVA10 present in } 49 \% \\
\text { Other viruses: CVA5, 6, 16, B1 and B3, echovirus 3, 4, and 9, and } \\
\text { EV71 }\end{array}$ & $\begin{array}{l}\text { The } 2008 \text { onychomadesis outbreak in Spain } \\
\text { was associated with HFMD caused primarily } \\
\text { by the CVA10 virus }\end{array}$ \\
\hline Tian et al. China 2011 [38] & $\begin{array}{l}147 \text { HFMD cases. Majority <3 years. } 69.4 \% \text { males } \\
\text { Rashes and fever } \geq 38.5{ }^{\circ} \mathrm{C} 100 \% \\
100 \% \text { CNS involvement (lethargy } 84.4 \% \text {, myoclonus } 51.7 \% \text {, } \\
\text { drowsiness } 23.1 \% \text { ), tachypnea } 76.2 \% \text {, bradypnea } 14.3 \% \text {, hyper- } \\
\text { tension } 15.5 \% \text {, increased chest } 51.7 \% \text {, consolidation of the } \\
\text { thorax } 29.9 \% \text {, hyperglycemia } 86.4 \% \text {, high levels of lactic acid } \\
88.4 \% \text {, positive EV71 } 76.9 \% \\
\text { Treatment: mechanical ventilation for } 61.2 \pm 12.8 \mathrm{~h} \text { (range } \\
\text { 40-96 h), mannitol, dexamethasone, gamma globulin, ribavirin, } \\
\text { dopamine (58.5\%), dobutamine ( } 51.0 \% \text { ), amrinone }(21.8 \%) \\
2 \% \text { Died during hospitalization. Everyone else had a full recovery } \\
\text { and were discharged after } 14.2 \pm 1.6 \text { days (range, } 12-17 \text { ) }\end{array}$ & $\begin{array}{l}\text { The central nervous system and cardiac } \\
\text { system are involved in patients with severe } \\
\text { HFMD. Fasting blood sugar and increased } \\
\text { lactic acid levels in the majority of patients } \\
\text { Mechanical ventilation support and drug } \\
\text { treatment are associated with good clinical } \\
\text { outcome of these patients }\end{array}$ \\
\hline $\begin{array}{l}\text { Wei et al. Taiwan, China } \\
2011 \text { [21] }\end{array}$ & $\begin{array}{l}130 \text { HFMD cases by CVA6 } \\
\text { Perioral rash ( } 22 \%) \text {, rash on body and/or neck (30\%), general rash } \\
(5 \%) \text {, hand-foot-mouth rash ( } 51 \%) \text {, peeling of palms and soles } \\
\text { of the feet (37\%), onychomadesis (5\%) }\end{array}$ & $\begin{array}{l}\text { Patients with CVA6 associated HFMD symp- } \\
\text { toms of infection saw a broader spectrum } \\
\text { of the destruction to the skin and deeper } \\
\text { tissues, such as nail abnormalities and } \\
\text { peeling }\end{array}$ \\
\hline Chang et al. Taiwan. [45] & $\begin{array}{l}219 \text { enterovirus } 71 \text { case subjects and } 97 \text { control children } \\
74 \% \text { (163 of } 219 \text { cases) were complicated cases, } 57 \% \text { ( } 125 \text { of } \\
219 \text { cases) are complicated cases with central nervous system } \\
\text { involvement, and } 17 \% \text { ( } 38 \text { of } 219 \text { cases) involved cardiopulmo- } \\
\text { nary failure after central nervous system involvement } \\
\text { Necrosis factor a promoter type II (-308 A allele), HLA-A33, and } \\
\text { HLA-DR17 were significantly associated with enterovirus } 71 \\
\text { susceptibility } \\
\text { HLA-A33 was the gene most significantly susceptible to entero- } \\
\text { virus } 71 \text {. HLA-A2 was associated with the development of } \\
\text { cardiopulmonary failure }\end{array}$ & $\begin{array}{l}\text { HLA-A33, which is a common phenotype in } \\
\text { Asian populations but is rare in white popu- } \\
\text { lations, was most significantly associated } \\
\text { with enterovirus } 71 \text { infection, compared } \\
\text { with the other candidate genes studied, } \\
\text { whereas HLA-A2 was significantly related to } \\
\text { cardiopulmonary failure }\end{array}$ \\
\hline
\end{tabular}

HFMD hand, foot and mouth disease, $S$ sensitivity, E specificity, $P P V$ positive predictive value, NPV negative predictive value

infection and later development into severe forms of the disease [44].

\section{Vaccine}

The EV71 vaccine is also important for preventing infection. Recent studies show that both serotypes of human leukocyte antigen, HLA-A33 (class I) and HLA-DR17 (class II), have significant associations with EV71 infection, suggesting that cellular immune response may play an important role in human immunity against EV71 infection [45]. It was also found that the most severe cases of EV71, characterized by pulmonary edema, had lower cell specific antigen cytokines (Th1) and a lower lymphocyte proliferation response to the EV71 antigen in comparison with milder cases. This suggests that cellular immune response correlates with the clinical severity of HFMD. Namely, induction of cellular and humoral immunity should be considered when developing vaccines and further analyzed in clinical trials [44]. In 2010, effective antiviral agents and vaccines against this virus was under 
Table 5 Epidemiological studies on the more severe forms of HFMD

\begin{tabular}{|c|c|c|}
\hline Study & Results & Conclusions \\
\hline $\begin{array}{l}\text { Liu et al. Shenzhen, } \\
\text { China } 2008 \text { [37] }\end{array}$ & $\begin{array}{l}145 \text { HFMD cases } \\
124 \text { mild cases } 35 \%+E V 71 \\
21 \text { severe cases } 67 \%+E V 71 \\
\text { Leukocytes and blood glucose levels of the most serious were signifi- } \\
\text { cantly elevated. Age was less in severe cases }(P<0.05)\end{array}$ & $\begin{array}{l}\text { EV71 mainly contributes to severe HFMD } \\
\text { High fever, elevated white blood cell count, } \\
\text { high blood glucose concentrations and } \\
\text { an age less than } 4 \text { years should be used } \\
\text { to predict severe cases }\end{array}$ \\
\hline $\begin{array}{l}\text { Ang et al. Singapore } \\
2009[49]\end{array}$ & $\begin{array}{l}\text { Annual incidence rate of HFMD rose from } 125.5 \text { in } 2001 \text { to } 435.9 \text { in } \\
2007 \text { per 100,000 habitants }\end{array}$ & $\begin{array}{l}\text { HFMD remains a major public health prob- } \\
\text { lem in Singapore. Must maintain a high } \\
\text { degree of vigilance, particularly for EV } 71\end{array}$ \\
\hline $\begin{array}{l}\text { Sarma et al. W. Bengal, } \\
\text { India } 2009[51]\end{array}$ & $\begin{array}{l}38 \text { HFMD cases. Children 1-12 years } \\
\text { M:F-21:17. Oral lesions } 86.6 \% . \text { High incidence of EV71 }\end{array}$ & $\begin{array}{l}\text { An alarmingly high prevalence of EV71. } \\
\text { No significant differences between boys } \\
\text { and girls }\end{array}$ \\
\hline $\begin{array}{l}\text { Wu et al. Hangzhou, } \\
\text { China } 2010[24]\end{array}$ & $\begin{array}{l}28 \text { HFMD cases } \\
\text { Severe cases }<2 \text { years } 88.89 \% \\
\text { Severe patients with EV71-92.86\% } \\
\text { Mild patients with EV71-36.51\% }\end{array}$ & $\begin{array}{l}\text { Children under } 2 \text { with EV71 are the highest } \\
\text { risk group for developing the severe form } \\
\text { of the disease }\end{array}$ \\
\hline $\begin{array}{l}\text { Suzuki et al. Tokyo, Japan } \\
2010 \text { [53] }\end{array}$ & $\begin{array}{l}199 \text { HFMD cases. Severe 96. Mild } 103 \\
\text { No differences in sex, age, family history. No significant association } \\
\text { between the center of care and disease presentation }\end{array}$ & $\begin{array}{l}\text { There is no clear association between } \\
\text { center of care and presentation. More } \\
\text { studies are needed in this regard }\end{array}$ \\
\hline $\begin{array}{l}\text { Zeng et al. Shangai, } \\
\text { China } 2012 \text { [26] }\end{array}$ & $\begin{array}{l}28,058 \text { HFMD cases } \\
\text { Neurological disorders, pulmonary edema and hemorrhage } 2.6 \% \\
0.04 \% \text { deaths } \\
\text { More cases in summer and higher frequency in boys than girls } \\
1 \text { - } 4 \text { years } 82.27 \% \\
\text { EV71 positive: } 99.17 \% \text { severe cases in } 2009,86.31 \% \text { in } 2010,100 \% \\
\text { of patients with neurological affectation, edema, pneumonia and } \\
\text { hemorrhage }\end{array}$ & $\begin{array}{l}\text { Dominant EV71 circulation led to the } \\
\text { outbreak of HFMD and the occurrence of } \\
\text { severe and fatal cases in China } \\
\text { EV71 is associated predominantly with } \\
\text { severe cases of the disease }\end{array}$ \\
\hline $\begin{array}{l}\text { Wang et al. Beijing, } \\
\text { China } 2011 \text { [2] }\end{array}$ & $\begin{array}{l}\text { Children } 1-3 \text { years } O R>2.3 \\
\text { Serious illness } O R>1.4 \\
\text { Death } O R>2.4 \\
\text { Children } O R=1.56 \text { boys compared to girls } \\
1 \text { day delay in diagnosis associated with severe disease increase } \\
\quad(40 \%) \text { and the probability of death }(54 \%) \\
\text { EV71 association with severe disease } O R=16 \text { and death } O R=40 \text {, } \\
\text { regarding CVA16 }\end{array}$ & $\begin{array}{l}\text { HFMD is transmissible especially among } \\
\text { preschoolers. Enterovirus } 71 \text { was } \\
\text { responsible for the most serious cases } \\
\text { and deaths in China. The mixture of } \\
\text { asymptomatic infected children in school } \\
\text { might have contributed to the spread of } \\
\text { infection. Diagnosis is very important to } \\
\text { reduce the high mortality rate }\end{array}$ \\
\hline $\begin{array}{l}\text { Fang et al. Shaoxing, } \\
\text { China } 2014 \text { [43] }\end{array}$ & 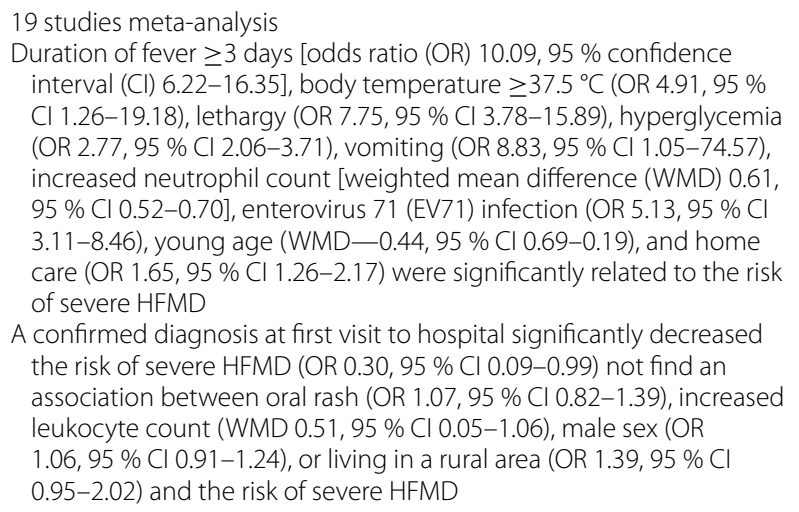 & $\begin{array}{l}\text { Duration of fever } \geq 3 \text { days, body tempera- } \\
\text { ture } \geq 37.5^{\circ} \mathrm{C} \text {, lethargy, hyperglycemia, } \\
\text { vomiting, increased neutrophil count, } \\
\text { EV71 infection, and young age are risk } \\
\text { factors for severe HFMD. A confirmed } \\
\text { diagnosis at first visit to hospital can } \\
\text { significantly decrease the risk of severe } \\
\text { HFMD }\end{array}$ \\
\hline $\begin{array}{l}\text { Chen et al. Shangai, } \\
\text { China [25] }\end{array}$ & $\begin{array}{l}\text { The mean serum VA concentration for all patients was } \\
0.73 \pm 0.26 \mathrm{mmol} / \mathrm{L} \text {, and } 237(52.7 \%) \text { of them presented low con- } \\
\text { centrations ( } \geq 0.7 \mathrm{mmol} / \mathrm{L}) \text {. Both serum concentrations of VA and } \\
\text { IFN-a in the patients with complications were significantly lower } \\
\text { than in patients without complications ( } \mathrm{P}<0.01 \text { ) } \\
\text { The decreased concentrations of IFN-a and EV71-lgM were positively } \\
\text { related to lower VA levels (correlation coefficient } 1 / 40.58 \text { and } 0.41 \text {, } \\
\text { respectively, } P<0.001 \text { ) }\end{array}$ & $\begin{array}{l}\text { VA status is associated with the antiviral } \\
\text { immunity and pathogenetic condition } \\
\text { of HFMD in young children. The children } \\
\text { with HFMD mostly presented low VA } \\
\text { concentrations and simultaneously } \\
\text { had lower serum IFNa levels, decreased } \\
\text { immune antibody production and more } \\
\text { severe illness }\end{array}$ \\
\hline
\end{tabular}


development [46], Another study, in 2012 presented the first construction and characterization of an infectious cDNA clone of CVA16. The availability of this infectious clone also improved virological investigations and CVA16 vaccine development [42]. For 2015, formalin-inactivated EV71 (FI-EV71) vaccines have been developed evaluated in human clinical trials, and were found to elicit full protection against EV71, and bivalent FI-EV71/FI-CVA16 vaccines have been found to elicit strong neutralizing antibody responses against both viruses in animal models, but nevertheless, there is currently no approved vaccine or antiviral substance available for the prevention or treatment of EV71 infection [47, 48].

\section{Prevention}

On another note, the HFMD patient is potentially contagious for the duration of the initial symptoms, until the vesiculobullous skin lesions disappear. Therefore, patients diagnosed with HFMD should be excluded from group participation until the fever and skin and mucosal lesions have disappeared. Furthermore, the virus is known to be shed in the feces for several weeks. It is therefore necessary for patients and family members to know that the disease is spread through direct contact with blisters and secretions from the nose and throat, as well as through hands or utensils contaminated with the feces or secretions of infected people. It is therefore important to emphasize washing hands well and to avoid sharing contaminated utensils. In the case we presented, up to four adults who were in direct contact with the infected child suffered from the disease, as in the case described by Shin et al. [6]. To prevent the infection from spreading to children and vulnerable adults, doctors and dentists should be aware that HFMD can also occur in immunocompetent adults [6]. It has also been shown that public health measures such as closing schools and hygiene campaigns are effective in reducing the incidence rate of HFMD [49].

Due to multiple pathogenic compositions, enteroviral recombination, co-infection, spreading and the lack of an effective vaccine, outbreaks of the infection can persist for a long time. It is therefore vitally important to carry out epidemic surveillance of this disease and its complications, and consequently clinicians should inform health authorities to promote citizen participation in dealing with large epidemics of HFMD [50,51].

Our case was resolved spontaneously with symptomatic treatment without complications over a period of $7-10$ days, as reflected in other articles $[6,13]$.

\section{Conclusions}

HFMD is a typical childhood illness, but it also occurs in adults, which should be kept in mind due to the possibility of outbreaks, with emphasis on medical history and the overall clinical picture, to avoid inadequate treatments with antibiotics.

Dentists have an advantage over other professionals in diagnosing the disease, as lesions in the oral cavity are the main symptoms that affect the patient, and the dentist is therefore frequently one of the first professionals to be consulted. Thus, knowledge of the disease and early detection prevents the infection from spreading to other children and adults. Similarly, dentists have a key role in educating patients by recommending good oral hygiene to minimize the spread of the disease.

A surveillance system to predict future outbreaks, appropriate public health measures and research into vaccine development are of vital importance to control HFMD.

\section{Consent}

Written informed consent was obtained from the patient for publication of this case report and any accompanying images.

\section{Abbreviations}

HFMD: hand foot and mouth disease; EV: enterovirus; CV: coxsackievirus; IVIG: intravenous immunoglobulin; SCARB2: scavenger receptor class B, member 2; FI-EV71: formalin inactivated enterovirus 71; FI-CVA16: formalin inactivated coxsackievirus 16.

\section{Authors' contributions}

$J \mathrm{LL}$ and EJS conceived and designed the study. COC, AMV, MSR and AMR performed the review and the case report. COC, AMV and JLL wrote the manuscript. All authors read and approved the final manuscript.

\section{Author details}

${ }^{1}$ School of Dentistry, University of Los Andes, Mérida, Venezuela. ${ }^{2}$ Department of Odontostomatology, School of Dentistry, University of Barcelona, L'Hospitalet de Llobregat, Barcelona, Spain. ${ }^{3}$ Oral Health and Masticatory System Group (Bellvitge Biomedical Research Institute) IDIBELL, University of Barcelona, L'Hospitalet de Llobregat, 08907 Barcelona, Spain. ${ }^{4}$ Department of Oral and Maxillofacial Surgery, University Hospital Bellvitge (HUB), c/Feixa Llarga, Hospitalet de Llobregat, 08907 Barcelona, Spain. ${ }^{5}$ Dental Hospital Barcelona University, Universitary Campus of Bellvitge, C/Feixa LLarga S/N, L'Hospitalet de Llobregat, 08907 Barcelona, Spain.

\section{Acknowledgements}

None.

\section{Competing interests}

The authors declare that they have no competing interests.

Received: 24 September 2015 Accepted: 3 March 2016

Published online: 15 March 2016

\section{References}

1. Robinson CR, Doane FW, Rhodes AJ. Report of an outbreak of febrile illness with pharyngeal lesions and exanthem: Toronto, summer 1957; isolation of group A coxsackie virus. Can Med Assoc J. 1958;79:615-21.

2. Wang JF, Guo YS, Christakos G, Yang WZ, Liao YL, Li ZJ, et al. Hand, foot and mouth disease: spatiotemporal transmission and climate. Int J Health Geogr. 2011;5:10-25.

3. Blomqvist S, Klemola P, Kaijalainen S, Paananen A, Simonen ML, Vuorinen T, et al. Co-circulation of coxsackieviruses A6 and A10 in hand, foot and mouth disease outbreak in Finland. J Clin Virol. 2010;48:49-54. 
4. Wang Y, Feng Z, Yang Y, Self S, Gao Y, Longini IM, et al. Hand, foot, and mouth disease in China: patterns of spread and transmissibility. Epidemiology. 2011;22:781-92.

5. Zhang X, Yan HP, Huang C, Tan YF, Ma DM, Zhang HP, et al. The etiology and clinical manifestations of 70 patients with hand-foot-mouth disease. Zhonghua Yu Fang Yi Xue Za Zhi. 2009;43:872-4.

6. Shin JU, Oh SH, Lee JH. A Case of Hand-foot-mouth Disease in an Immunocompetent Adult. Ann Dermatol. 2010;22:216-8.

7. Ooi MH, Wong SC, Mohan A, Podin Y, Perera D, Clear D, et al. Identification and validation of clinical predictors for the risk of neurological involvement in children with hand, foot, and mouth disease in Sarawak. BMC Infect Dis. 2009;19:9.

8. Cui L, Qi Y, Li H, Ge Y, Zhao K, Qi X, et al. Serum microRNA expression profile distinguishes enterovirus 71 and coxsackievirus 16 infections in patients with hand-foot-and-mouth disease. PLoS One. 2011;6:11.

9. Kaminska, et al. Coxsackievirus A6 and hand, foot and mouth disease: three case reports of familial child-to-immunocompetent adult transmission and a literature review. Case Rep Dermatol. 2013;5:203-9.

10. Campbell L, Chu Y, Introcaso C, Schaffer A, James W. Coxsackievirus A6induced hand-foot-mouth disease. JAMA Dermatol. 2013;149(12):1419_ 21. doi:10.1001/jamadermatol.2013.6777.

11. Harris P, Wang A, Mo Yin, Kiat Lee C, Archuleta S. Atypical hand, foot, and mouth disease: eczema coxsackium can also occur in adults. Lancet Infect Dis. 2014:14:1043.

12. Park SK, Park B, Ki M, Kim H, Lee K, Jung C, et al. Transmission of seasonal outbreak of childhood enteroviral aseptic meningitis and hand-footmouth disease. J Korean Med Sci. 2010;25:677-83.

13. Delgado W, Concha H, Guevara J. Infección de la mucosa oral por coxsackie virus: enfermedad de boca mano pie. Rev Estomatol Herediana. 2007; 17:35-9

14. Liu MY, Liu W, Luo J, Liu Y, Zhu Y, Berman H, et al. Characterization of an outbreak of hand, foot, and mouth disease in Nanchang, China in 2010. PLoS One. 2011:6:9.

15. Akiyama K, Imazeki R, Yoshii F, Koide T, Muto J. An adult case of hand, foot, and mouth disease caused by enterovirus 71 accompanied by opsoclonus myoclonica. Tokai J Exp Clin Med. 2008;33:143-5.

16. Agrawal R, Bhan K, Balaggan K, Lee R, Pavesio C, Addison P. Unilateral acute maculopathy associated with adult onset hand, foot and mouth disease: case report and review of literatura. J Ophthalmic Inflamm Infect. 2015;5:2.

17. Muppa R, Bhupatiraju P, Duddu M, Dandempally A. Hand, foot and mouth disease. J Indian Soc Pedod Prev Dent. 2011;29:165-7.

18. Cao R, Han J, Qin E, Qin C. Mechanism of intravenous immunoglobulin therapy for severe hand-foot-mouth disease: a review. Sheng Wu Gong Cheng Xue Bao. 2011;27:712-6.

19. Davia JL, Bel PH, Ninet VZ, Bracho MA, González-Candelas F, Salazar A, et al. Onychomadesis outbreak in Valencia, Spain associated with hand, foot, and mouth disease caused by enteroviruses. Pediatr Dermatol. 2011;28:1-5.

20. Guimbao J, Rodrigo P, Alberto MJ, Omeñaca M. Onychomadesis outbreak linked to hand, foot, and mouth disease, Spain, July 2008. Euro Surveill. 2010;16:15-37.

21. Wei SH, Huang YP, Lin MC, Tsung-Pei T, Hui-Chen L, Tsuey-Li L, et al. An outbreak of coxsackievirus A6 hand, foot, and mouth disease associated with onychomadesis in Taiwan, 2010. BMC Infect Dis. 2011;14:11-346.

22. Russo DH, Luchs A, Machado BC, Carmona Rde C, Timenetsky Mdo C. Echovirus 4 associated to hand, foot and mouth disease. Rev Inst Med Trop Sao Paulo. 2006:48:197-9.

23. Cho HK, Lee NY, Lee H, Kim HS, Seo JW, Hong YM, et al. Enterovirus 71-associated hand, foot and mouth diseases with neurologic symptoms, a university hospital experience in Korea, 2009. Korean J Pediatr. 2010;53:639-43

24. Wu YD, Shang SQ, Chen ZM, Yang ZH. Analysis of the epidemic characteristics of the etiological agents in children with hand, foot and mouth disease and its clinical significance. Zhonghua Er Ke Za Zhi. 2010;48:535-9.

25. Chen S, Yang Y, Yan X, Chen J, Yu H, Wang W. Influence of vitamin A status on the antiviral immunity of children with hand, foot and mouth disease. Clin Nutr. 2012;31:543-8

26. Zeng M, Li YF, Wang XH, Lu GP, Shen HG, Yu H, et al. Epidemiology of hand, foot, and mouth disease in children in Shanghai 2007-2010. Epidemiol Infect. 2012;140:1122-30
27. Zhu JP, Xu ZG, Chen H, Zhang X, Fan DY, Wang J. Primary detection of pathogen from children with hand, foot, and mouth disease in Beijing, 2007. Bing Du Xue Bao. 2009;25:23-8.

28. Alsop J, Flewett TH, Foster JR. "Hand-foot-and-mouth disease" in Birmingham in 1959. Br Med J. 1960;2:1708-11.

29. Hii YL, Rocklöv J, Ng N. Short term effects of weather on hand, foot and mouth disease. PLoS One. 2011;6:e16796.

30. Yan XF, Gao S, Xia JF, Ye R, Yu H, Long JE. Epidemic characteristics of hand, foot, and mouth disease in Shanghai from 2009 to 2010: enterovirus 71 subgenotype $C 4$ as the primary causative agent and a high incidence of mixed infections with coxsackievirus A16. Scand J Infect Dis. 2012;44:297-305.

31. Osterback R, Vuorinen T, Linna M, Susi P, Hyypiä T, Waris M. Coxsackievirus $A 6$ and hand, foot, and mouth disease, Finland. Emerg Infect Dis. 2009;15:1485-8

32. Yang F, Zhang T, Hu Y, Wang X, Du J, Li Y, et al. Survey of enterovirus infections from hand, foot and mouth disease outbreak in China, 2009. Virol J. 2011;8:508.

33. Centers for Disease Control and Prevention (CDC). Notes from the field: severe hand, foot, and mouth disease associated with coxsackievirus A6-Alabama, Connecticut, California, and Nevada, November 2011-February 2012. MMWR Morb Mortal Wkly Rep. 2012;61:213-4.

34. Hu X, Zhang Y, Zhou X, Xu B, Yang M, Wang M, et al. Simultaneously typing nine serotypes of enteroviruses associated with hand, foot and mouth disease by a GeXP anaylizer-based multiplex RT-PCR assay. J Clin Microbiol. 2012;50:288-93.

35. Na SY, Son YM, Lee HY, Baek JO, Roh JY, Lee JR. A case of varicella combined with hand-foot-mouth disease in a healthy child. Ann Dermatol. 2009:21:98-101.

36. Yu N, Guo M, He SJ, Pan YX, Chen XX, Ding XX, et al. Evaluation of human enterovirus 71 and coxsackievirus A16 specific immunoglobulin M antibodies for diagnosis of hand-foot-and-mouth disease. Virol J. 2012;9:12.

37. Liu YX, Xie JJ, He YX, Liu WL, Zhang MX, Le XH, et al. Study of the clinical and laboratory features of hand-foot-mouth disease. Zhonghua Shi Yan He Lin Chuang Bing Du Xue Za Zhi. 2008;22:475-7.

38. Tian H, Yang QZ, Liang J, Dong SY, Liu ZJ, Wang LX. Clinical features and management outcomes of severe hand, foot and mouth disease. Med Princ Pract. 2012;21:355-9.

39. He YX, Fu D, Cao DZ, Liu HY, Huang QL, Li CR. Critical care and therapy based different illness state of 80 patients with severe hand-footand-mouth disease seen in Shenzhen. Zhonghua Er Ke Za Zhi. 2009;47:338-43

40. Zhang D, Jiayuang $L$, Jiahai L. Enterovirus 71 vaccine: close but still far. Int J Infect Dis. 2010;14:e739-43.

41. Yang C, Deng C, Wan J, Zhu L, Leng Q. Neutralizing antibody response in the patients with hand, foot and mouth disease to enterovirus 71 and its clinical implications. Virol J. 2011;16:306.

42. Li Y, Zhu R, Qian Y, Deng J. The characteristics of blood glucose and WBC counts in peripheral blood of cases of hand foot and mouth disease in China: a systematic review. PLoS One. 2012;7:e29003.

43. Fang $Y$, Wang $S$, Zhang L, Guo Z, Huang Z, Tu C. Risk factors of severe hand, foot and mouth disease: a meta-analysis. Scand J Infect Dis. 2014:46:515-22

44. Yamayoshi S, Fujii K, Koike S. Scavenger receptor b2 as a receptor for hand, foot, and mouth disease and severe neurological diseases. Front Microbiol. 2012;3:32

45. Chang LY, Chang IS, Chen WJ, Huang YC, Chen GW, Shih SR, et al. HLA-A33 is associated with susceptibility to enterovirus 71 infection. Pediatrics. 2008;122:1271-6.

46. Liu F, Liu Q, Cai Y, Leng Q, Huang Z. Construction and characterization of an infectious clone of coxsackievirus A16. Virol J. 2011;8:534.

47. Chia-Chyi L, Yen-Hung C, Pele B, Kleinc M. Prospect and challenges for the development of multivalent vaccines against hand, foot and mouth diseases. Vaccine. 2014;32:6177-82.

48. Pourianfar $\mathrm{H}$, Grollo L. Development of antiviral agents toward enterovirus 71 infection. J Microbiol Immunol Infect. 2015;48:1e8.

49. Ang LW, Koh BK, Chan KP, Chua LT, James L, Goh KT. Epidemiology and control of hand, foot and mouth disease in Singapore, 2001-2007. Ann Acad Med Singapore. 2009;38:106-12. 
50. Ma E, Wong S, Wong C, Chuang SK, Tsang T. Effects of public health interventions in reducing transmission of hand, foot, and mouth disease. Pediatr Infect Dis J. 2011;30:432-5.

51. Sarma N, Sarkar A, Mukherjee A, Ghosh A, Dhar S, Malakar R. Epidemic of hand, foot and mouth disease in West Bengal, India in August, 2007: a multicentric study. Indian J Dermatol. 2009;54:26-30.
52. Rabenau HF, Richter M, Doerr HW. Hand, foot and mouth disease: seroprevalence of coxsackie A16 and enterovirus 71 in Germany. Med Microbiol Immunol. 2010;199:45-51.

53. Suzuki Y, Taya K, Nakashima K, Ohyama T, Kobayashi JM, Ohkusa Y, et al. Risk factors for severe hand foot and mouth disease. Pediatr Int. 2010;52:203-7.
Submit your next manuscript to BioMed Central and we will help you at every step:

- We accept pre-submission inquiries

- Our selector tool helps you to find the most relevant journal

- We provide round the clock customer support

- Convenient online submission

- Thorough peer review

- Inclusion in PubMed and all major indexing services

- Maximum visibility for your research

Submit your manuscript at www.biomedcentral.com/submit
(OioMed Central 